\title{
DISTRIBUSI FREKUENSI PANJANG, HUBUNGAN PANJANG TUBUH, PANJANG KLASPER, DAN NISBAH KELAMIN CUCUT LANJAMAN (Carcharhinus falciformis)
}

\author{
Dharmadi'), Fahmi'), dan Mohammad Adrim ${ }^{2)}$ \\ 1) Peneliti pada Pusat Riset Perikanan Tangkap, Ancol-Jakarta \\ 2) Peneliti pada Pusat Penelitian Oseanologi, Lembaga IImu Pengetahuan Indonesia-Ancol, Jakarta
}

Teregristrasi I tanggal: 13 Pebruari 2007; Diterima setelah perbaikan tanggal: 8 Maret 2007; Disetujui terbit tanggal: 24 Nopember 2007

\begin{abstract}
ABSTRAK
Cucut lanjaman (C. falciformis) merupakan salah satu jenis cucut dari famili Carcharhinidae yang umum tertangkap di perairan Samudera Hindia dengan alat tangkap rawai cucut, rawai tuna, dan jaring insang tuna. Penelitian ini dilakukan pada bulan April 2001 sampai dengan Desember 2004 di beberapa tempat pendaratan ikan dan pasar ikan di Pelabuhanratu, Cilacap, Kedonganan-Bali, dan Tanjung Luar-Lombok. Hasil penelitian menunjukkan bahwa hubungan antara panjang total dengan panjang klasper terlihat eksponensial, dengan nilai $\mathrm{R}^{2}=0,8218$ (untuk klasper yang belum berisi zat kapur), dan nilai $R^{2}=0,8197$ (untuk klasper yang sebagian berisi zat kapur), dan linier dengan nilai $\mathrm{R}^{2}=0,7529$ (untuk klasper yang penuh dengan zat kapur). Korelasi antara panjang klasper dengan panjang total tubuh cucut semakin kecil dengan semakin bertambah zat kapur dalam klasper. Frekuensi panjang terendah pada cucut lanjaman betina antara 51 sampai dengan $60 \mathrm{~cm}$ dan 241 sampai dengan $250 \mathrm{~cm}$ dan frekuensi panjang tertinggi antara 181 sampai dengan $190 \mathrm{~cm}$. Pada cucut lanjaman jantan, frekuensi panjang terendah 251 sampai dengan $260 \mathrm{~cm}$ dan tertinggi antara 181 sampai dengan $190 \mathrm{~cm}$. Sedangkan nisbah kelamin jantan dan betina cucut lanjaman mendekati 1:1 (51:49\%). Nilai perbandingan nisbah kelamin suatu spesies dapat disebabkan oleh ketersediaan ikan dan selektivitas alat tangkap.
\end{abstract}

\section{KATAKUNCI: panjang total, nisbah kelamin, cucut lanjaman}

ABSTRACT: Length distribution, frequency, body length relationship, clasper length and sex ratio of silky shark (C. falciformis). By: Dharmadi, Fahmi, and Mohammad Adrim

Silky shark (C. falciformis) is one of the family Carcharhinidae community caught by shark longlin from, drift tuna long line and drift gill net in the Indian Ocean. This study was conducted between April 2001 to December 2004 at some fish landing sites an or fish market i.e. Palabuhanratu, Cilacap, Kedonganan-Bali, and Tanjung Luar-Lombok. Results showed relationship between total length and clasper length was exponential $\left(R^{2}=0.8218\right)$, for not calcification clasper, and $\left(R^{2}=0.8197\right)$ for not full calcification clasper, and linier $\left(R^{2}=0.7529\right)$ for full calcification claspe. The correlation of clasper length and total length of silky shark tend to be smaller with in creasing calcificated content and clasper. The lowest length frequency of female silky shark was 51 to $60 \mathrm{~cm}$ and 241 to $250 \mathrm{~cm}$, and the highest length frequency was 181 to $190 \mathrm{~cm}$. Lowest length frequency of male silky shark was 251 to $260 \mathrm{~cm}$ and the highest was 181 to $190 \mathrm{~cm}$. While sex ratio of male and female was mostly 1:1 (51: 49\%). Variation of sex ratio occured due to the availability of fish and the selectivity of the fishing gear.

\section{KEYWORDS: $\quad$ total length, clasper length, sex ratio, silky shark}

\section{PENDAHULUAN}

Carcharhinus falciformis termasuk dalam famili Carcharhinidae (Whaler sharks), menurut Garrick (1982); Compagno (1984) famili ini paling tinggi kelimpahan dan tersebar secara berkelompok di perairan pantai tropis.

Cucut lanjaman merupakan sebutan dari jenis cucut Carcharhinus falciformis (silky shark) yang umum dikenal oleh nelayan di Jawa Tengah (Cilacap), nelayan di Bali mengatakan hiu mungsing atau hiu lancur dan nelayan di Lombok-Nusa Tenggara Barat mengenal dengan sebutan hiu lonjor atau kejen atau merak bulu (White et al., 2006). Jenis cucut ini sangat umum tertangkap oleh nelayan yang melakukan penangkapan di perairan Samudera Hindia dengan menggunakan pancing rawai cucut, rawai tuna permukaan, maupun dengan jaring insang tuna. Carcharhinus falciformis merupakan salah satu jenis cucut pelagis yang dapat mencapai ukuran panjang total 3,3 $\mathrm{m}$. Spesies ini hidup di perairan tropis dan 
sub tropis pada permukaan perairan sampai dengan pada kedalaman mendekati $500 \mathrm{~m}$, mempunyai karakteristik biologi pada setiap kelompok ukuran yang berbeda-beda. Kelompok ukuran muda terpisah dengan kelompok ukuran dewasa, ukuran muda berada di daerah pemijahan, sedangkan ukuran dewasa bermigrasi ke daerah perairan lain (Oshitani et al., 2003). Selanjutnya, dikatakan bahwa di lautan Pasifik sekitar 2 sampai dengan $30 \%$ cucut lanjaman tertangkap dengan pancing rawai. Di lautan Pasifik barat cucut lanjaman merupakan hasil tangkapan terbanyak dari beberapa jenis cucut lain dan diperkirakan sekitar $25 \%$ dari hasil tangkapan total cucut. Berbagai ukuran cucut lanjaman tertangkap oleh nelayan di perairan Samudera Hindia baik dengan menggunakan rawai maupun jaring insang. Dari beberapa lokasi pendaratan ikan yang berbeda di peroleh ukuran yang bervariasi, tergantung dari jenis alat tangkap yang digunakan dan daerah penangkapan.

Alat kelamin jantan atau klasper pada cucut dapat digunakan untuk mengetahui tingkat kematangan kelamin pada sejumlah spesies (Clark \& von Schmidt 1965; Teshima et al., 1978; Teshima, 1981; Parson 1983). Sementara itu, informasi tentang aspek biologi dari C. falciformis sampai dengan saat ini sangat sedikit, bahkan untuk kawasan perairan Indonesia dapat dikatakan belum tersedia. Informasi distribusi frekuensi panjang, hubungan panjang tubuh-panjang klasper, dan nisbah kelamin cucut lanjaman (Carcharhinus falciformis) setidaknya dapat digunakan sebagai dasar untuk melakukan penelitian lebih lanjut tentang pengkajian stok sumber daya. Secara biologi, hubungan antara panjang klasper dan panjang total dapat digunakan untuk mengetahui tingkat kematangan kelamin jantan pada ukuran tertentu dari ikan cucut lanjaman.

\section{BAHAN DAN METODE}

Bahan tulisan ini merupakan bagian dari hasil kegiatan penelitian yang telah dibiayai oleh proyek ACIAR-CSIRO Australia. Penelitian ini dilakukan pada tahun 2001 sampai dengan 2004 di beberapa tempat pendaratan ikan utama yaitu di Pelabuhan Perikanan Samudera Cilacap, Pelabuhan Perikanan Nusantara Palabuhanratu, Tempat Pendaratan Ikan Kedonganan-Bali, dan Pelabuhan Pendaratan Ikan Tanjung Luar-Lombok Timur. Pengamatan aspek biologi meliputi panjang tubuh, nisbah kelamin serta panjang klasper, dilakukan dengan pengukuran dan pengamatan langsung secara visual di lapangan. Jumlah contoh cucut yang diamati 432 ekor yang terdiri atas jantan dan betina. Pengukuran klasper dalam satuan centimeter yang diukur dari lekukan bagian dalam dari sirip perut sampai dengan ke bagian ujung klasper. Data yang dianalisis merupakan data gabungan yang berasal dari ke-4 lokasi pengamatan yaitu di Pelabuhanratu, Cilacap, Kedonganan-Bali, dan Tanjung Luar Lombok Timur dengan daerah penangkapan sama yaitu di perairan Samudera Hindia. Hasil tangkapan cucut yang didaratkan di 4 lokasi pendaratan ikan tersebut dianggap sebagai 1 unit stok. Analisis data untuk mengetahui korelasi antara 2 parameter yang diukur dilakukan dengan menggunakan statistik regresi berdasarkan pada Software Minitab Release 13. Rumus persamaan regresi yang digunakan adalah (persamaan linier, $y=0,0996 x-2,0169$, persamaan power, $y=3 E-13 x^{5,9369}$ dan persamaan exponensial, $y=0,5588 \mathrm{e}^{0,0124 x}$ ). Untuk mengetahui tingkat perkembangan klasper secara mikroskopis pada cucut lanjaman mengacu pada Martin \& Coillet (1988a); Snelson et al. (1988) dalam White et al. (2001) seperti pada Tabel Lampiran 1. Sedangkan hasil pengukuran panjang total cucut lanjaman yang dilakukan selama tahun 2001 sampai dengan 2004 di beberapa tempat pendaratan ikan disajikan pada Tabel Lampiran 2a, b, c, d, dan frekuensi panjang dan nisbah kelamin di Tabel Lampiran 3.

\section{HASIL DAN BAHASAN}

\section{Cucut Lanjaman}

Secara umum, morfologi cucut lanjaman dicirikan oleh pangkal sirip punggung pertama berada dibelakang ujung belakang sirip dada. Sisi bagian dalam sirip punggung ke-2 sangat panjang berukuran antara 1,6 sampai dengan 3,0 kali tinggi sirip. Di antara sirip punggung cucut lanjaman tidak terdapat gurat, dan jika dilihat dari arah bawah bentuk moncong agak panjang, bulat, dan menyempit. Sedangkan gigi atas kecil dengan lekukan di 1 sisi, gigi bawah kecil, ramping, dan tegak (White et al., 2006).

Cucut lanjaman hidup di perairan oseanik dan pelagis, tetapi lebih banyak terdapat di lepas pantai dekat dengan daratan, dekat dengan permukaan, tetapi kadang-kadang dijumpai sampai dengan kedalaman $500 \mathrm{~m}$. Cucut ini bereproduksi secara vivipar dengan kuning telur berupa plasenta (yolk-sac placenta), jumlah anak yang dihasilkan antara 1 sampai dengan 16 ekor. Jenis cucut betina dapat berbiak setiap tahun, tetapi reproduksi tidak musiman dan makanan utama terdiri atas ikan, kelompok cumi, dan krustacea (Compagno, 1984). Jenis cucut ini sering tertangkap dengan rawai permukaan maupun jaring insang di perairan Samudera Hindia antara 


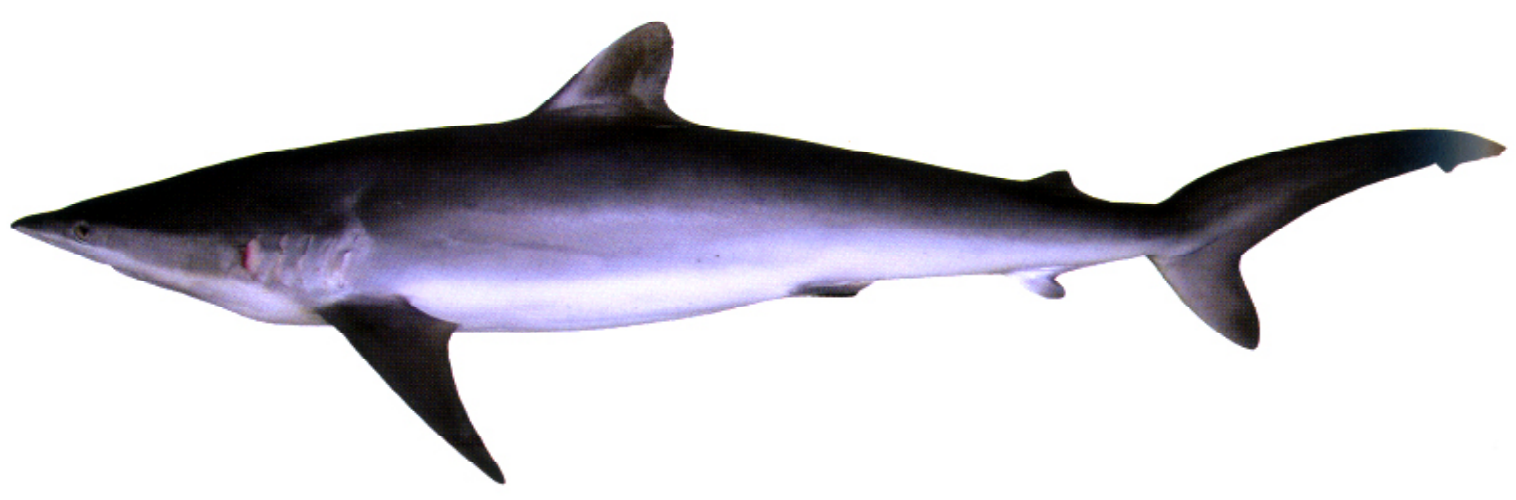

Gambar 1. Morfologi cucut lanjaman (Carcharhinus falciformis) atau silky shark. Figure 1. Morphology of silky shark (Carcharhinus falciformis) atau silky shark.

Lombok dan perairan bagian utara Australian pada posisi geografi antara 9 sampai dengan $14^{\circ}$ lintang selatan dan antara 116 sampai dengan $119^{\circ}$ bujur timur. Kegiatan penangkapan cucut di perairan tersebut dilakukan oleh para nelayan yang mendaratkan hasil tangkapan di Tanjung LuarLombok. Cucut yang tertangkap merupakan sasaran tangkap utama dengan alat tangkap rawai cucut permukaan dan rawai cucut dasar, dan sebagai hasil tangkapan sampingan dari alat tangkap jaring insang permukaan.

\section{Distribusi Frekuensi Panjang}

Data frekuensi panjang merupakan salah satu parameter yang dapat digunakan untuk mengetahui parameter pertumbuhan dari suatu spesies ikan (Sparre \& Venema, 1992). Dari hasil pengamatan ukuran panjang cucut lanjaman di 4 lokasi pendaratan ikan (Pelabuhan ratu, Cilacap, Kedonganan, dan Tanjung Luar) dalam tahun 2001 sampai dengan 2004, diperoleh bahwa frekuensi panjang terendah pada cucut lanjaman betina antara 51 sampai dengan 60 $\mathrm{cm}$ dengan modus $55 \mathrm{~cm}$ untuk ukuran muda dan 241 sampai dengan $250 \mathrm{~cm}$ dengan modus $245 \mathrm{~cm}$ untuk ukuran dewasa dan frekuensi panjang tertinggi antara 181 sampai dengan $190 \mathrm{~cm}$ dengan modus $185 \mathrm{~cm}$. Pada cucut lanjaman jantan, frekuensi panjang terendah adalah 251 sampai dengan $260 \mathrm{~cm}$ dengan modus $255 \mathrm{~cm}$ dan tertinggi antara 181 sampai dengan $190 \mathrm{~cm}$ dengan modus $185 \mathrm{~cm}$. Frekuensi panjang tertinggi pada cucut lanjaman jantan dan betina terdapat pada modus yang sama namun sedikit berbeda dalam jumlah, sebaliknya pada frekuensi panjang terendah baik pada cucut lanjaman jantan maupun betina diperoleh jumlah yang sama namun memiliki ukuran yang berbeda (Gambar 2). Dari gambar tersebut tampak bahwa contoh cucut lanjaman jantan paling tidak terdiri atas 3 kelompok umur dengan modus sebaran panjang masing-masing 85,135 , dan $185 \mathrm{~cm}$ sedangkan cucut betina paling tidak terdapat 4 kelompok umur dengan modus sebaran panjang $85,115,185$, dan $235 \mathrm{~cm}$. Dengan melihat pola pertumbuhan antara kelompok umur dengan modus 85 sampai dengan $185 \mathrm{~cm}$ diduga terdiri atas beberapa kelompok umur yang tumpang tindih.

Menurut White et al. (2006), ukuran panjang total cucut lanjaman dapat mencapai $350 \mathrm{~cm}$ atau paling tidak mencapai $250 \mathrm{~cm}$. Sedangkan di perairan Malaysia pada spesies yang sama ukuran dapat mencapai panjang total $330 \mathrm{~cm}$ (Yano et al., 2005). Ukuran panjang total cucut lanjaman yang tertangkap di perairan Samudera Hindia yang didaratkan di Tanjung Luar $260 \mathrm{~cm}$, dengan frekuensi tertinggi terdapat pada ukuran $190 \mathrm{~cm}$. Hal ini, menunjukkan bahwa cucut lanjaman yang tertangkap di perairan Samudera Hindia selama tahun 2001 sampai dengan 2004 yang didaratkan di 4 lokasi pendaratan ikan (Pelabuhanratu, Cilacap, Kedonganan, dan Tanjung Luar) sebagian besar relatif muda yang memiliki ukuran panjang total antara 51 sampai dengan $190 \mathrm{~cm}$. Menurut Bartron (2006) cucut lanjaman berukuran panjang total $186,4 \mathrm{~cm}$ berumur 9 tahun yang diduga termasuk dalam kelompok cucut muda, sedangkan cucut lanjaman yang memiliki panjang total $242,9 \mathrm{~cm}$ berumur 19 tahun yang termasuk dalam kelompok cucut dewasa atau tua. Secara morfologi, perbedaan cucut muda dan dewasa diduga dapat diketahui dari ukuran panjang, kelompok cucut muda memiliki ukuran lebih pendek dibanding dengan kelompok cucut dewasa. Kelompok cucut lanjaman muda yang tertangkap di perairan Samudera Hindia yang 
didaratkan di 4 lokasi pendaratan ikan tersebut memiliki ukuran antara 51 sampai dengan $190 \mathrm{~cm}$ dan kelompok dewasa berukuran antara 191 sampai dengan $280 \mathrm{~cm}$. Perbedaan kondisi perairan dari 1 wilayah ke wilayah dapat berpengaruh terhadap perbedaan ukuran kematangan kelamin baik terhadap jantan maupun betina cucut lanjaman. Oshitani et al. (2003) mengatakan di lautan Pasifik kematangan kelamin jantan terdapat pada ukuran 200 sampai dengan $206 \mathrm{~cm}$ atau berumur 5 sampai dengan 6 tahun, untuk jenis betina dijumpai pada ukuran 186 $\mathrm{cm}$ atau berumur antara 6 sampai dengan 7 tahun, sedangkan di lautan Atlantik cucut lanjaman jantan matang kelamin terjadi pada ukuran antara 210 sampai dengan 220 yang berumur 6 sampai dengan 7 tahun dan pada jenis betina terdapat pada ukuran $225 \mathrm{~cm}$ yang berumur antara 7 sampai dengan 9 tahun.
Dari hasil penelitian sebagian besar $(66,4 \%)$ cucut lanjaman yang tertangkap berukuran relatif muda. Kondisi demikian akan mengganggu keseimbangan populasi, karena penangkapan yang dilakukan secara terus-menerus akan menyebabkan banyak cucut yang berukuran sedang (muda) tertangkap, sehingga dapat terjadi growth over fishing yaitu suatu tingkat penangkapan di mana ikan-ikan muda banyak tertangkap sebelum mencapai pertumbuhan optimum (Pitcher \& Hart, 1982), dan menyebabkan kemungkinan terjadi pengurangan ikan-ikan dewasa. Akibat growth over fishing ada kemungkinan terjadi recruitment over fishing atau suatu tingkat penangkapan di mana ketersediaan ikan-ikan matang menurun karena penambahan individu yang dihasilkan tidak cukup untuk mempertahankan populasi. Dengan kata lain, bahwa proses pertumbuhan dan

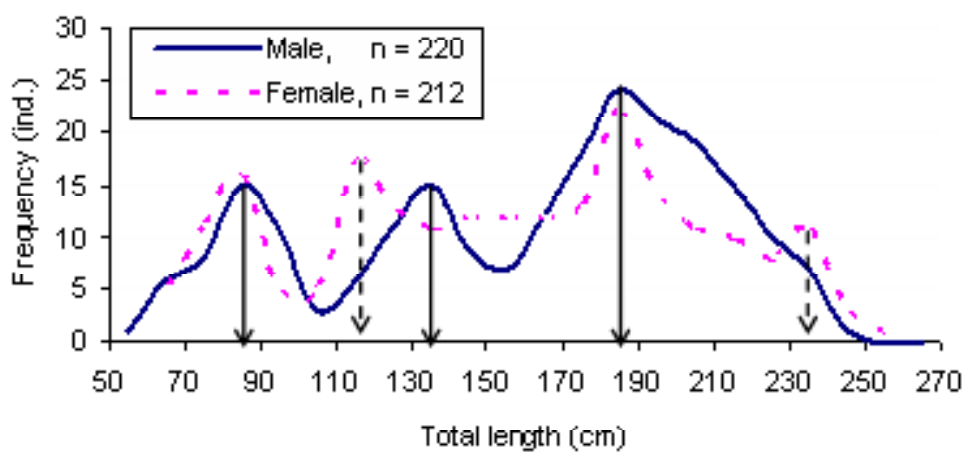

Gambar 2. Distribusi panjang cucut lanjaman yang tertangkap di perairan Samudera Hindia. Figure 2. Length distribution of Silky shark caught in the Indian Ocean.

rekruitmen suatu spesies tidak dapat berlangsung dengan baik apabila terjadi penangkapan yang dilakukan secara terus-menerus tanpa terkendali. Keberhasilan proses rekruitmen suatu spesies kemungkinan dipengaruhi oleh beberapa faktor yaitu daerah penangkapan, alat tangkap yang digunakan dan ukuran ikan yang tertangkap (Sparre \& Venema, 1992). Proses rekruitmen suatu spesies dapat juga dipengaruhi oleh faktor kualitas lingkungan perairan, densitas induk yang tersedia, dan ada tidak pemangsa atau predator. Kendati demikian jenis cucut ini dalam daftar buku merah yang ditetapkan oleh International Union for Conservation of Nature berada dalam status konservasi kurang mengkawatirkan (White et al., 2006), hal ini karena populasi dianggap cukup berlimpah dibanding dengan jenis cucut lain yang masuk dalam status konservasi hampir terancam antara lain Carcharhinus plumbeus, C. obscurus, $C$. melanopterus, dan C. macloti (White et al., 2006).

Seberapa besar kelimpahan cucut lanjaman di perairan Samudera Hindia diperlukan penelitian lebih
Ianjut. Hasil penelitian Oshitani et al., 2003 menunjukkan bahwa cucut lanjaman betina dalam kondisi bunting di lautan Pasifik terjadi pada ukuran antara 115 sampai dengan $215 \mathrm{~cm}$. Tetapi ukuran matang gonad diperkirakan mendekati ukuran panjang antara 145 sampai dengan $150 \mathrm{~cm}$. Kematangan kelamin cucut lanjaman betina dapat juga dicapai pada ukuran panjang sekitar 220 dan $200 \mathrm{~cm}$ untuk jenis kelamin jantan (wikipedia.org). Selama penelitian berlangsung hanya berhasil diamati 8 ekor cucut lanjaman betina yang diketahui tingkat kematangan gonad, terutama di tempat pendaratan ikan Tanjung Luar-Lombok yang dilakukan pada bulan April, Juli, September, dan Oktober 2004 (Tabel Lampiran 2). Dari contoh yang diperoleh diketahui bahwa tingkat kematangan gonad pertama terdapat pada ukuran panjang antara 77,1 sampai dengan $133,9 \mathrm{~cm}$ di mana kondisi ovari belum berkembang. Tingkat kematangan gonad ke-2 pada ukuran panjang antara 191,6 sampai dengan 203,7 cm dengan kondisi ovari mulai berkembang, tidak ditemukan tingkat kematangan gonad ke-3 dalam contoh dan hanya terdapat 1 ekor 
dengan tingkat kematangan gonad ke-4 berukuran panjang 250,2 cm yang ditandai dengan terdapat banyak telur dan embrio. Untuk mengetahui tingkat kematangan gonad yang lebih akurat diperlukan jumlah contoh yang lebih banyak.

Glenn (1993) menjelaskan bahwa perkembangan indung telur dapat digunakan sebagai indikator untuk mengetahui tingkat kematangan gonad pada ikan cucut. Di Pantai Florida ikan cucut martil betina Sphyrna tiburo (famili Carcharhinidae) berukuran panjang total kurang dari $65 \mathrm{~cm}$ termasuk belum matang gonad, indung telur belum berkembang, dan berdiameter telur 1 sampai dengan $2 \mathrm{~mm}$. Pada ukuran panjang total antara 65 sampai dengan $70 \mathrm{~cm}$ ovarium mulai berkembang. Perkembangan gonad mulai terjadi pada telur berdiameter kurang lebih $2 \mathrm{~cm}$ dengan panjang total tubuh ikan cucut antara 80 sampai dengan $85 \mathrm{~cm}$.

\section{Hubungan Panjang Klasper dengan Panjang Total}

Klasper adalah alat kelamin jantan pada ikan bertulang rawan yang merupakan perpanjangan tulang bagian dalam dari sirip perut atau modifikasi sirip perut yang membentuk saluran sperma yang berfungsi menyalurkan sperma ke kloaka (organ reproduksi) betina atau organ kopulasi untuk memudahkan proses pembuahan secara internal. Terjadi perkembangan klasper dimungkinkan karena koordinasi perkembangan otot-otot yang diperlukan untuk memompa sperma dan menggerakkan klasper (Grogan \& Lund dalam Carrier et. al., 2004). Klasper pada cucut jantan dapat digunakan untuk mengetahui tingkat kematangan kelamin pada spesies cucut (Clark \& von Schmidt, 1965; Teshima et al., 1978; Teshima, 1981; Parsons, 1983). Kondisi klasper pada cucut lanjaman selama pengamatan yang dilakukan tahun 2001 sampai dengan 2004 di tempat pendaratan ikan Cilacap, Pelabuhanratu, Kedonganan, dan Tanjung Luar menunjukkan tingkatan yang berbeda yaitu klasper dalam keadaan kosong tanpa zat kapur, klasper berisi sebagian zat kapur dan klasper dalam kondisi penuh zat kapur. Zat kapur merupakan zat yang sangat dibutuhkan dalam proses perkembangan kematangan kelamin jantan yang berfungsi untuk mengeraskan klasper. Hubungan antara panjang total dengan panjang klasper terlihat eksponensial, dengan nilai $R^{2}=0,8218$ (untuk klasper yang belum berisi zat kapur), dan $\mathrm{R}^{2}=0,8197$ (untuk klasper yang sebagian berisi zat kapur), dan linier dengan nilai $R^{2}=0,7529$ (untuk klasper yang penuh dengan zat kapur) (Gambar 3 a, b, dan c). Hal ini, menunjukkan bahwa terjadi korelasi positif antara panjang klasper dengan panjang total tubuh yang berarti dengan bertambah panjang klasper akan diiringi dengan bertambah panjang total tubuh cucut. Namun demikian, hubungan ke-2 variabel tersebut tergantung pada kondisi klasper. Semakin berisi zat kapur pada klasper, hubungan antara panjang klasper, dan panjang total tubuh cucut semakin kecil, dengan perkataan lain pada kondisi klasper yang dipenuhi zat kapur ukuran panjang tidak
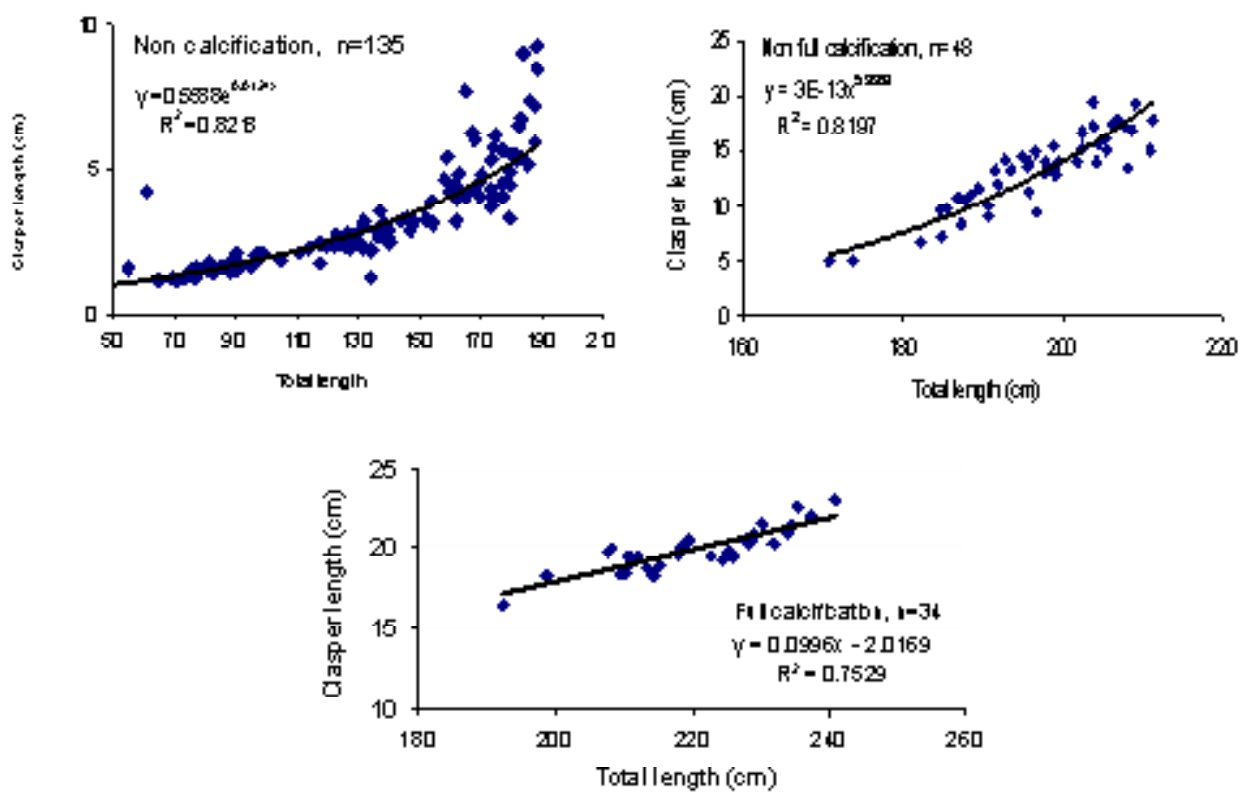

Gambar $3(\mathrm{a}, \mathrm{b}, \mathrm{c})$. Hubungan antara panjang klasper dengan panjang total tubuh cucut lanjaman.

Figure $3(a, b, c)$. Relationship of clasper length and total length of Silky shark. 
terdapat hubungan yang erat dengan panjang total tubuh. Pada klasper yang tidak mengandung zat kapur (Gambar 3a) menunjukkan bahwa panjang ukuran klasper terendah 1,2 cm dengan panjang total 71,2 cm dan tertinggi pada ukuran klasper 9,2 cm dengan panjang total $189,1 \mathrm{~cm}$. Pada klasper yang sebagian berisi zat kapur diperoleh ukuran panjang terendah $49 \mathrm{~mm}$ dengan panjang total $173,8 \mathrm{~cm}$ dan ukuran tertinggi $193 \mathrm{~mm}$ dengan panjang total $2.090 \mathrm{~mm}$ (Gambar 3b). Sedangkan klasper yang penuh mengandung zat kapur diperoleh ukuran klasper terendah $16,5 \mathrm{~cm}$ dengan panjang total $192,4 \mathrm{~cm}$ dan tertinggi $22,2 \mathrm{~cm}$ dengan panjang total $235,3 \mathrm{~cm}$ terjadi pada bulan September 2004 yang diperoleh dari tempat pendaratan ikan di Tanjung Luar (Gambar 3c). Perkembangan klasper pada ikan cucut martil (Spyrna tiburo) famili Carcharhinidae diilustrasikan oleh Glenn (1993), ikan cucut yang berukuran antara 55 sampai dengan $60 \mathrm{cmm}$ sudah memperlihatkan perkembangan klasper dan mulai menunjukkan kematangan kelamin. Sedangkan kematangan kelamin terjadi pada ikan cucut berukuran panjang total antara 68 sampai dengan $70 \mathrm{~cm}$, di mana ukuran klasper kira-kira $8 \%$ dari ukuran panjang total ikan cucut.

\section{Nisbah Kelamin}

Perbandingan kelamin atau nisbah kelamin merupakan aspek yang sangat penting bagi kemampuan individu dalam proses rekruitmen populasi spesies (www.enclycopedia.com). Proses rekruitmen suatu spesies ikan akan berhasil apabila perbandingan jumlah jantan dan betina dalam 1 populasi seimbang. Berdasarkan pada hasil pengamatan terhadap 432 ekor cucut lanjaman diperoleh jenis kelamin jantan 220 ekor dan betina 212 ekor dengan perbandingan antara jantan betina 51:49\% (Lampiran 3). Berdasarkan pada uji $X^{2}$ diperoleh nilai=19,530 ( $p>0,05)$, yang berarti bahwa perbandingan jantan dan betina berbeda nyata. Perbandingan tersebut kurang ideal untuk keberlangsungan proses reproduksi suatu spesies di suatu perairan, karena peluang dalam memperoleh pasangan untuk tujuan reproduksi akan berkurang atau individu spesies jantan berkompetisi dengan individu jantan lain untuk mendapatkan pasangan. Suwarso et al. (2000) mengatakan bahwa variasi perbandingan nisbah kelamin dapat disebabkan oleh ketersediaan ikan dan selektivitas alat tangkap. Tetapi hal ini berlaku untuk perikanan pelagis kecil, sedangkan untuk perikanan pelagis besar khususnya golongan ikan yang termasuk Elasmobranchii (ikan cucut), selektivitas alat tangkap tidak dapat diterapkan karena sebagian besar cucut yang tertangkap baik dengan menggunakan alat tangkap rawai maupun jaring terdiri atas berbagai macam ukuran.

\section{KESIMPULAN}

Modus cucut lanjaman $190 \mathrm{~cm}$, sehingga ukuran tersebut termasuk dalam kelompok cucut berumur muda. Berdasarkan pada kondisi klasper, hubungan antara panjang total dan panjang klasper memperlihatkan hubungan yang eksponensial dan linier. Namun, hubungan ke-2 variabel tersebut semakin kecil dengan semakin berkurang zat kapur dalam klasper. Hubungan antara panjang klasper dan panjang total dapat digunakan sebagai dasar untuk mengetahui tingkat kematangan kelamin pada cucut jantan. Berdasarkan pada uji $X^{2}$, maka perbandingan nisbah kelamin cucut lanjaman jantan dan betina kurang ideal untuk keberlangsungan proses reproduksi, karena dalam suatu populasi untuk mendapatkan pasangan dalam bereproduksi individu jantan berkompetisi dengan individu jantan lain.

\section{UCAPAN TERIMA KASIH}

Penulis menyampaikan ucapan terima kasih pada ACIAR-CSIRO Australia terutama pada Dr. Steve Blaber sebagai pemimpin proyek penelitian yang berlangsung sejak tahun 2001 sampai dengan 2006. Ucapan terima kasih juga disampaikan pada Dr. William White sebagai counterpart atas kerja sama yang baik selama pelaksanaan penelitian berlangsung.

\section{PERSANTUNAN}

Kegiatan dari hasil riset perikanan artisanal cucut dan pari di perairan Indonesia Timur: Sosial ekonomi dan karakteristik perikanan hubungannya dengan sumber daya perikanan di perairan Australia, tahun 2001-2006, ACIAR-CSIRO Australia.

\section{DAFTAR PUSTAKA}

Bartron, C., W. T. White, Dharmadi, \& C. Potter. 2006. Biology of the Silky Shark Carcharhinus falciformis (Carcharhinidae) in the eastern Indian Ocean where it is commercially important (In press).

Carrier, J. C., J. A. Musick, \& M. R. Herthaus. 2004. Biology of Sharks and their relatives. Texbook. CRC Press. Washington D. C. 596 p.

Clark, E. \& K. von Schmidt. 1965. Shark of the central gulf coat of Florida. Bulletin Marine Science. 15: 13-83. 
Compagno, L. J. V. 1984. FAO species catalogue. Vol.4. Sharks of the world. An annotated and illustrated catalogue of shark species known to date. Part 2-Carcharhiniformes. FAO Fish. Synopsis. (125) Vol.4. Pt.250-655.

Garrick, J. A. F. 1982. Sharks of the genus Carcharhinus NOAA Tech. Rep. N. M. F. S. Circular. (445): 1-194.

Glenn R. P. 1993. Geographic variation in reproduction between two population of the bonnethead shark, Sphyrna tiburo. Environmental Biology of Fsheries. 38: 25-35. Kluvier Academic Publisher. Netherlands. 25-35 p.

http//en.wikipedia.org/wiki/Silky shark.

Oshitani, S. H. Nakano, \& S. Tanaka. 2003. Age and growth of the silky shark Carcharhinus falciformis from the Pacific Ocean. Fisheries Science. 2003. 69: 456-464.

Parsons, G. R. 1983. The reproductive biology of the Atlantic sharpnose shark, Rhizoprionodon terraenovae. U. S. Fisheries Bulletin. 81: 61-73.

Pitcher, T. J. \& P. J. B. Hart. 1982. Fisheries Ecology American. Edition. The AVI Publishing Company. INC. Westport. Connecticut. 408 p.

Sparre, P. \& Venema S. C. 1992. Introduction to tropical fish stock assessment. Part I-Manual. FAO Fisheries Technical paper. 306/1. Rev.1. Danida FAO. Rome. Italy. 376 hal.

Suwarso, Dharmadi, \& J. Widodo. 2000. Biology and fishery of Malalugis biru, Mackerel Scad, Decapterus macarellus, in North Sulawesi Waters of Indonesia. Proceedings of the JSPS-DGHE International Symposium. Sustainable Fisheries in Asia in the New millennium. Faculty of Fisheries and Marine Science-Institut Pertanian Bogor Bogor-Indonesia. August 21-25. 552 p.

Teshima, K., M. Ahmad, \& K. Mizue. 1978. Studies on sharks-14. Reproduction in the Telok Anson shark collected from Perak River. Malaysia. Jap. Journal. Ichthyology. 25: 181-189.

Teshima, K. 1981. Studies on the reproduction of Japanese smooth dogfishes, Mustelus manazo and M. griseus. The Journal of Shimonoseki University of Fisheries. 29: 113-199.

White W. T., M. E. Platell, \& I. C. Potter. 2001. Relationship between reproductive biology and age composition and growth in Urolophus lobatus (Batoidea: Urolophidae). Marine Biology. 138: 135147.

White, W. T., P. R. Last, J. D. Stevens, G. K. Yearsley, Fahmi, \& Dharmadi. 2006. Economically important sharks and rays of Indonesia. National Library of Australia Cataloging-in-Publication entry. Australia. $329 \mathrm{p}$.

Yano, K., A. Ali, A. C. Gambang, I. A. Hamid, S. A. Razak, \& A. Zainal. 2005. Sharks and rays of Malaysia and Brunei Darussalam. Marine Fishery Research Development and Management Departement Southeast Asian Fisheries Development Center. Terengganu, Malaysia. 213 p.

www.encyclopedia.com. Male-biased sex ratio of fish embryos near a pulp mill: Temporary recovery after a shout-term shutdown (Research Article). 
Lampiran 1. Tingkat kematangan kelamin jantan pada ikan bertulang rawan

Appendix 1. Sex maturity stage of male elasmobranch

\begin{tabular}{|c|c|c|}
\hline No. & $\begin{array}{l}\text { Tingkat kematangan } \\
\text { kelamin/Stage of } \\
\text { maturity }\end{array}$ & $\begin{array}{l}\text { Perkembangan secara mikroskopis/ } \\
\text { Microskopic development }\end{array}$ \\
\hline 1. & Belum matang & $\begin{array}{l}\text { Testis belum berkembang, klasper berukuran kecil dan belum terjadi } \\
\text { pengapuran. }\end{array}$ \\
\hline 2. & Sedang berkembang & $\begin{array}{l}\text { Testis membesar tapi tanpa lubang-lubang di permukaan, vas deferens } \\
\text { (saluran sperma) membulat. Klasper membesar, mulai terjadi } \\
\text { pengapuran dan kaku. }\end{array}$ \\
\hline 3. & Matang, belum bereproduksi & $\begin{array}{l}\text { Lubang-lubang pada testis membengkak disebabkan memproduksi } \\
\text { sperma. Saluran sperma membulat kencang. Klasper sangat } \\
\text { berkembang dan kaku disebabkan oleh zat kapur. }\end{array}$ \\
\hline 4. & Matang & $\begin{array}{l}\text { Seminal vesikel penuh spermatozoa yang sudah matang. Lubang- } \\
\text { lubang permukaan testis dan klasper membesar dan kaku. }\end{array}$ \\
\hline
\end{tabular}

Sumber/Sources: Martin \& Coillet (1988a); Snelson et al. (1988) dalam White et al. (2001)

Lampiran 2a. Hasil pengukuran panjang total cucut lanjaman (C. falciformis) di tempat pendaratan ikan Cilacap, tahun 2001 sampai dengan 2004

Appendix 2a. Total length measurements $(\mathrm{cm})$ of Silky shark (C. falciformis) at Cilacap landing site in 2001 until 2004

\begin{tabular}{|c|c|c|c|c|c|c|c|}
\hline \multicolumn{2}{|c|}{2001} & \multicolumn{4}{|c|}{2002} & \multicolumn{2}{|c|}{2004} \\
\hline April & Juli & Maret & Juni & Oktober & Agustus & Juli & September \\
\hline $136(\mathrm{M})$ & $680(\mathrm{M})$ & $1.470(\mathrm{M})$ & $1.710(\mathrm{M})$ & $1.410(\mathrm{~F})$ & $1.460(\mathrm{~F})$ & $978(\mathrm{~F})$ & $833(F)$ \\
\hline $138,0(\mathrm{M})$ & $84,0(F)$ & $100,0(F)$ & $72,0(\mathrm{M})$ & $129,0(\mathrm{M})$ & $135,0(\mathrm{M})$ & $89,1(\mathrm{M})$ & $83,3(\mathrm{~F})$ \\
\hline $135,0(F)$ & $90,0(\mathrm{~F})$ & $74,1(F)$ & $72,0(F)$ & $120,0(\mathrm{M})$ & $117,0(\mathrm{~F})$ & $89,7(F)$ & $75,5(F)$ \\
\hline $95,0(F)$ & $99,0(\mathrm{~F})$ & $89,2(\mathrm{M})$ & $111,0(\mathrm{M})$ & $123,0(\mathrm{M})$ & $127,0(\mathrm{~F})$ & $194,6(F)$ & 86,3 (M) \\
\hline $105,0(\mathrm{M})$ & $138,0(\mathrm{M})$ & $82,3(F)$ & $89,0(\mathrm{~F})$ & $124,0(F)$ & $83,0(F)$ & $169,0(\mathrm{~F})$ & $122,5(\mathrm{M})$ \\
\hline $107,0(\mathrm{~F})$ & $70,0(F)$ & & $122,0(F)$ & $114,0(\mathrm{M})$ & $84,5(\mathrm{M})$ & & $161,5(\mathrm{M})$ \\
\hline \multirow[t]{19}{*}{$76,0(F)$} & $126,0(F)$ & & & $74,0(\mathrm{M})$ & $89,0(\mathrm{M})$ & & $101,9(F)$ \\
\hline & & & & $75,0(\mathrm{M})$ & $88,0(\mathrm{M})$ & & $79,2(F)$ \\
\hline & & & & $75,0(\mathrm{~F})$ & $88,0(\mathrm{M})$ & & $84,7(F)$ \\
\hline & & & & $76,0(F)$ & 79,0 (M) & & $77,0(\mathrm{~F})$ \\
\hline & & & & $77,0(F)$ & $78,0(F)$ & & $107,5(\mathrm{M})$ \\
\hline & & & & $77,0(\mathrm{M})$ & $78,0(\mathrm{~F})$ & & $109,3(F)$ \\
\hline & & & & $78,0(\mathrm{M})$ & 76,8 (M) & & $71,3(F)$ \\
\hline & & & & $88,0(\mathrm{M})$ & $76,8(F)$ & & $114,4(F)$ \\
\hline & & & & $66,0(\mathrm{M})$ & $77,0(\mathrm{~F})$ & & 83,7 (M) \\
\hline & & & & $66,0(F)$ & $73,0(F)$ & & $96,1(\mathrm{M})$ \\
\hline & & & & $67,0(F)$ & & & $99,2(\mathrm{M})$ \\
\hline & & & & $68,0(\mathrm{M})$ & & & $109,8(F)$ \\
\hline & & & & $68,0(\mathrm{M})$ & & & $79,2(\mathrm{~F})$ \\
\hline & & & & $68,0(\mathrm{~F})$ & & & 75,7 (M) \\
\hline & & & & $70,0(\mathrm{~F})$ & & & 77,8 (M) \\
\hline & & & & $70,0(\mathrm{~F})$ & & & $105,3(\mathrm{M})$ \\
\hline & & & & $73,0(\mathrm{M})$ & & & \\
\hline & & & & $69,0(\mathrm{~F})$ & & & \\
\hline & & & & $69,0(\mathrm{M})$ & & & \\
\hline
\end{tabular}


Lampiran 2b. Hasil pengukuran panjang total cucut lanjaman (C. falciformis) di tempat pendaratan ikan Pelabuhanratu, tahun 2001 sampai dengan 2003

Appendix 2b. Total l ength measurements (cm) of Silky shark (C. falciformis) at Pelabuhanratu landing site in 2001 until 2003

\begin{tabular}{|c|c|c|c|c|c|c|c|}
\hline \multicolumn{2}{|c|}{2001} & \multicolumn{5}{|c|}{2002} & \multirow{2}{*}{$\begin{array}{c}2003 \\
\text { Pebruari/ } \\
\text { February }\end{array}$} \\
\hline $\begin{array}{c}\text { April/ } \\
\text { April }\end{array}$ & $\begin{array}{l}\text { Juli/ } \\
\text { July }\end{array}$ & $\begin{array}{l}\text { Pebruari/ } \\
\text { February }\end{array}$ & $\begin{array}{l}\text { Maret/ } \\
\text { March }\end{array}$ & $\begin{array}{l}\text { Juni/ } \\
\text { June }\end{array}$ & $\begin{array}{l}\text { Agustus/ } \\
\text { August }\end{array}$ & $\begin{array}{l}\text { Oktober/ } \\
\text { october }\end{array}$ & \\
\hline $138,0(\mathrm{M})$ & $93,0(F)$ & $77,5(F)$ & $136,0(\mathrm{M})$ & $171,0(\mathrm{M})$ & $146,0(F)$ & $141,0(\mathrm{~F})$ & $73,0(F)$ \\
\hline $116,0(\mathrm{M})$ & $97,6(\mathrm{M})$ & $77,5(\mathrm{M})$ & $135,0(\mathrm{M})$ & $72,0(\mathrm{M})$ & $135,0(\mathrm{M})$ & $129,0(\mathrm{M})$ & $75,0(\mathrm{M})$ \\
\hline $128,0(\mathrm{M})$ & & $114,0(F)$ & $121,0(\mathrm{M})$ & $72,0(\mathrm{~F})$ & $117,0(F)$ & $120,0(\mathrm{M})$ & \\
\hline \multirow[t]{22}{*}{$113,0(\mathrm{M})$} & & $88,0(\mathrm{M})$ & $110,0(\mathrm{M})$ & $111,0(\mathrm{M})$ & $127,0(F)$ & $123,0(\mathrm{M})$ & \\
\hline & & $90,0(\mathrm{M})$ & $120,0(F)$ & $89,0(\mathrm{~F})$ & $83,0(F)$ & $124,0(F)$ & \\
\hline & & $119,0(\mathrm{M})$ & $206,0(\mathrm{M})$ & $122,0(\mathrm{~F})$ & $84,5(\mathrm{M})$ & $114,0(\mathrm{M})$ & \\
\hline & & $119,0(\mathrm{M})$ & $115,2(F)$ & & $89,0(\mathrm{M})$ & $74,0(\mathrm{M})$ & \\
\hline & & $134,5(\mathrm{M})$ & $85,5(F)$ & & $88,0(\mathrm{M})$ & $75,0(\mathrm{M})$ & \\
\hline & & $87,5(\mathrm{M})$ & $107,0(F)$ & & $88,0(\mathrm{M})$ & $75,0(F)$ & \\
\hline & & $84,5(F)$ & $90,0(\mathrm{M})$ & & $79,0(\mathrm{M})$ & $76,0(\mathrm{~F})$ & \\
\hline & & $81,0(\mathrm{M})$ & $145,0(F)$ & & $78,0(F)$ & $77,0(\mathrm{~F})$ & \\
\hline & & $82,0(\mathrm{M})$ & $147,0(\mathrm{M})$ & & $78,0(\mathrm{~F})$ & $77,0(\mathrm{M})$ & \\
\hline & & $83,0(\mathrm{M})$ & $100,0(F)$ & & $76,8(\mathrm{M})$ & $78,0(\mathrm{M})$ & \\
\hline & & $111,0(\mathrm{M})$ & $74,1(F)$ & & $76,8(F)$ & $88,0(\mathrm{M})$ & \\
\hline & & & $89,2(\mathrm{M})$ & & $77,0(\mathrm{~F})$ & $66,0(\mathrm{M})$ & \\
\hline & & & $82,3(F)$ & & $73,0(F)$ & $66,0(\mathrm{~F})$ & \\
\hline & & & & & & $67,0(\mathrm{~F})$ & \\
\hline & & & & & & $68,0(\mathrm{M})$ & \\
\hline & & & & & & $68,0(\mathrm{M})$ & \\
\hline & & & & & & $68,0(\mathrm{~F})$ & \\
\hline & & & & & & $70,0(\mathrm{~F})$ & \\
\hline & & & & & & $70,0(\mathrm{~F})$ & \\
\hline & & & & & & $73,0(\mathrm{M})$ & \\
\hline & & & & & & $69,0(\mathrm{~F})$ & \\
\hline & & & & & & $69,0(\mathrm{M})$ & \\
\hline
\end{tabular}

Lampiran 2c. Hasil pengukuran panjang total cucut lanjaman (C. falciformis) di tempat pendaratan ikan Kedonganan, tahun 2002 dan 2004

Appendix 2c. Total length measurements $(\mathrm{cm})$ of Silky shark (C. falciformis) at Kedonganan landing site in 2002 and 2004

\begin{tabular}{cc}
\hline Bulan Juni 2002 & Bulan April 2004 \\
\hline $94,6(\mathrm{~F})$ & $78,4(\mathrm{M})$ \\
$76,0(\mathrm{~F})$ & $86,0(\mathrm{~F})$ \\
& $86,6(\mathrm{M})$ \\
& $101,0(\mathrm{M})$ \\
& $105,3(\mathrm{~F})$ \\
& $121,0(\mathrm{~F})$ \\
\hline
\end{tabular}


Lampiran 2d. Hasil pengukuran panjang total cucut lanjaman (C. falciformis) di tempat pendaratan ikan Tanjung Luar, 2001 sampai dengan 2004

Appendix 2d. Total length measurements (cm) of Silky shark (C. falciformis) at Tanjung Luar landing site in 2001 until 2004

\begin{tabular}{|c|c|c|c|c|c|c|c|c|}
\hline \multicolumn{2}{|c|}{2001} & \multicolumn{4}{|c|}{2002} & \multicolumn{3}{|c|}{2004} \\
\hline $\begin{array}{l}\text { April/ } \\
\text { April }\end{array}$ & $\begin{array}{l}\text { Juli/ } \\
\text { July }\end{array}$ & $\begin{array}{l}\text { Maret/ } \\
\text { March }\end{array}$ & $\begin{array}{l}\text { Juni/ } \\
\text { June }\end{array}$ & $\begin{array}{l}\text { Agustus/ } \\
\text { August }\end{array}$ & $\begin{array}{l}\text { Oktober/ } \\
\text { October }\end{array}$ & $\begin{array}{l}\text { April/ } \\
\text { April }\end{array}$ & $\begin{array}{l}\text { Juli/ } \\
\text { July }\end{array}$ & $\begin{array}{l}\text { September/ } \\
\text { September }\end{array}$ \\
\hline $217,0(\mathrm{M})$ & $254,0(F)$ & $142,0(\mathrm{M})$ & $190,0(F)$ & $216,5(F)$ & $213,0(F)$ & $84,3(\mathrm{M})$ & $1.373(\mathrm{M})$ & $127,7(M)$ \\
\hline $220,0(\mathrm{M})$ & $227,0(M)$ & $74,0(F)$ & $191,0(F)$ & $231,0(\mathrm{M})$ & $215,0(M)$ & $86,7(M)$ & $1.241(F)$ & $130,3(F)$ \\
\hline $252,0(F)$ & $223,0(F)$ & $78,0(M)$ & $191,2(F)$ & $238,0(F)$ & $215,1(F)$ & $94,2(\mathrm{M})$ & $1.638(\mathrm{M})$ & $155,6(\mathrm{M})$ \\
\hline $212,0(F)$ & $126,0(F)$ & $79,0(F)$ & $203,0(M)$ & $191,5(F)$ & $220,2(M)$ & $103,1(\mathrm{M})$ & $1.298(F)$ & $199,2(\mathrm{M})$ \\
\hline $171,0(F)$ & $127,0(F)$ & & $168,0(F)$ & $191,5(\mathrm{M})$ & $225,0(M)$ & $120,1 \mathrm{M})$ & $1350(\mathrm{M})$ & $196,1(M)$ \\
\hline $187,0(F)$ & $135,0(\mathrm{M})$ & & $175,2(F)$ & $201,0(F)$ & $192,0(\mathrm{M})$ & $122,0 \mathrm{M})$ & $2.053(\mathrm{M})$ & $195,0(\mathrm{M})$ \\
\hline \multirow[t]{47}{*}{$188,0(\mathrm{M})$} & $137,0(\mathrm{M})$ & & $160,0(\mathrm{M})$ & $173,0(F)$ & $194,0(F)$ & $134,1(\mathrm{M})$ & $819(F)$ & $218,6(M)$ \\
\hline & $138,0(F)$ & & $163,0(M)$ & $174,0(\mathrm{M})$ & $200,4(M)$ & $140,1 \mathrm{M})$ & $751(F)$ & $135,3(F)$ \\
\hline & $140,0(\mathrm{M})$ & & $162,0(F)$ & $165,0(F)$ & $182,7(F)$ & $142,7(F)$ & $1.040(F)$ & $169,5(M)$ \\
\hline & $152,0(\mathrm{M})$ & & $156,5(\mathrm{M})$ & $154,0(F)$ & $179,0(F)$ & $144,9(F)$ & $806(M)$ & $201,2(F)$ \\
\hline & $188,0(F)$ & & $65,0(F)$ & $155,0(F)$ & $181,0(F)$ & $146,1(F)$ & $852(M)$ & $216,1(M)$ \\
\hline & $193,0(\mathrm{M})$ & & $67,0(M)$ & $155,0(F)$ & $156,9(F)$ & $148,2 \mathrm{M})$ & $981(\mathrm{M})$ & $211,6(F)$ \\
\hline & $197,0(\mathrm{M})$ & & $69,0(F)$ & $140,5(F)$ & $108,0(\mathrm{M})$ & $150,1(F)$ & $780(F)$ & $69,6(F)$ \\
\hline & $200,0(\mathrm{M})$ & & $139,2(F)$ & $132,0(\mathrm{M})$ & $112,0(\mathrm{M})$ & $150,1(F)$ & $1.062(\mathrm{M})$ & $126,0(F)$ \\
\hline & $206,0(\mathrm{M})$ & & $148,5(\mathrm{M})$ & $132,0(F)$ & $86,2(F)$ & $156,6 \mathrm{M})$ & $882(\mathrm{~F})$ & $193,4(\mathrm{M})$ \\
\hline & $210,0(F)$ & & $150,0(F)$ & $132,5(F)$ & $87,0(F)$ & $157,6(F)$ & 988 M) & $219,4(\mathrm{M})$ \\
\hline & $182,0(F)$ & & $69,5(\mathrm{M})$ & $159,0(F)$ & $90,0(\mathrm{~F})$ & $161,2 \mathrm{M})$ & $650(F)$ & $235,3(\mathrm{M})$ \\
\hline & & & $70,2(F)$ & $125,5(F)$ & $94,0(\mathrm{M})$ & $162,2(F)$ & $1.112(\mathrm{M})$ & $77,5(F)$ \\
\hline & & & $72,1(F)$ & $82,5(M)$ & & $162,2(\mathrm{M})$ & & $66,4(F)$ \\
\hline & & & $75,5(\mathrm{M})$ & $123,0(\mathrm{M})$ & & $162,6(\mathrm{M})$ & & $75,0(F)$ \\
\hline & & & $111,5(F)$ & $134,5(\mathrm{M})$ & & $163,1(F)$ & $1.475(F)$ & $77,3(F)$ \\
\hline & & & $113,0(F)$ & $140,0(F)$ & & $163,2(F)$ & $1.673(F)$ & $80,7(\mathrm{M})$ \\
\hline & & & $76,0(\mathrm{M})$ & $145,5(F)$ & & $163,2 \mathrm{M})$ & $1.339(F)$ & $81,5(\mathrm{M})$ \\
\hline & & & $96,0(\mathrm{M})$ & & & $166,1(F)$ & $1.677(F)$ & $82,0(M)$ \\
\hline & & & $99,0(\mathrm{M})$ & & & $169,2(F)$ & $1.970(\mathrm{M})$ & $87,1(F)$ \\
\hline & & & $107,5(\mathrm{M})$ & & & $169,5(F)$ & $1.354(\mathrm{M})$ & $99,8(\mathrm{M})$ \\
\hline & & & $105,0(F)$ & & & $172,1(\mathrm{M})$ & $743(F)$ & $101,0(F)$ \\
\hline & & & $105,0(F)$ & & & $174,1(F)$ & $890(\mathrm{M})$ & $101,5(F)$ \\
\hline & & & $120,5(F)$ & & & $175,6(F)$ & $893(F)$ & $102,1(F)$ \\
\hline & & & $122,0(\mathrm{M})$ & & & $175,6(\mathrm{M})$ & & $102,7(F)$ \\
\hline & & & $122,0(\mathrm{M})$ & & & $176,1(F)$ & & $104,4(M)$ \\
\hline & & & & & & $176,5 \mathrm{M})$ & & $108,3(F)$ \\
\hline & & & & & & $181,2 \mathrm{M})$ & & $110,4(F)$ \\
\hline & & & & & & $182,0 \mathrm{M})$ & & $112,9(F)$ \\
\hline & & & & & & $182,2(F)$ & & $115,3(F)$ \\
\hline & & & & & & $182,2(\mathrm{M})$ & & $118,3(M)$ \\
\hline & & & & & & 182,4 M) & & $122,8(\mathrm{M})$ \\
\hline & & & & & & $183,2(F)$ & & $127,0(F)$ \\
\hline & & & & & & $185,6(F)$ & & $127,8(F)$ \\
\hline & & & & & & $185,6(F)$ & & $128,0(\mathrm{M})$ \\
\hline & & & & & & $188,1(F)$ & & $141,7(M)$ \\
\hline & & & & & & $188,4(F)$ & & $142,1(F)$ \\
\hline & & & & & & $189,3(\mathrm{M})$ & & $142,9(F)$ \\
\hline & & & & & & & & $145,0(F)$ \\
\hline & & & & & & & & $145,7(M)$ \\
\hline & & & & & & $192,0(F)$ & & $147,3(F)$ \\
\hline & & & & & & $192,0(F)$ & & $159,3(\mathrm{M})$ \\
\hline & & & & & & $193,5(F)$ & & $198,8(\mathrm{M})$ \\
\hline & & & & & & $194,0 \mathrm{M})$ & & \\
\hline & & & & & & $194,4(\mathrm{M})$ & & $205,5(M)$ \\
\hline & & & & & & $194,6(\mathrm{M})$ & & $230,6(\mathrm{M})$ \\
\hline & & & & & & $195,4(\mathrm{M})$ & & $85,3(F)$ \\
\hline & & & & & & $196,1(F)$ & & $122,7(\mathrm{M})$ \\
\hline
\end{tabular}


Lampiran 2d. Lanjutan

Appendix 2d. Continue

\begin{tabular}{|c|c|c|c|c|c|c|c|c|c|}
\hline \multicolumn{2}{|c|}{2001} & \multicolumn{4}{|c|}{2002} & \multicolumn{4}{|c|}{2004} \\
\hline April & Juli & Maret & Juni & Agustus & Oktober & April & Juli & September & Oktober \\
\hline & & & & & & $197,0(F)$ & & $104,3(\mathrm{M})$ & \\
\hline & & & & & & $198,8(F)$ & & $89,0(F)$ & \\
\hline & & & & & & $201,5(F)$ & & 129,6 (M) & \\
\hline & & & & & & $203,5(F)$ & & $80,3(\mathrm{M})$ & \\
\hline & & & & & & $204,0(F)$ & & $122,7(\mathrm{M})$ & \\
\hline & & & & & & $204,2(F)$ & & $132,3(F)$ & \\
\hline & & & & & & 207,0 M) & & 118,1 (M) & \\
\hline & & & & & & $207,7(\mathrm{M})$ & & $112,0(\mathrm{M})$ & \\
\hline & & & & & & $207,8(\mathrm{M})$ & & $133,2(\mathrm{M})$ & \\
\hline & & & & & & $208,5(F)$ & & $107,6(\mathrm{M})$ & \\
\hline & & & & & & $208,7(F)$ & & $105,0(\mathrm{M})$ & \\
\hline & & & & & & $217,4(F)$ & & $105,6(\mathrm{M})$ & \\
\hline & & & & & & $217,8(\mathrm{M})$ & & $143,5(F)$ & \\
\hline & & & & & & $222,5 \mathrm{M})$ & & $135,6(F)$ & \\
\hline & & & & & & $224,1 \mathrm{M})$ & & $141,0(F)$ & \\
\hline & & & & & & $225,0(\mathrm{M})$ & & $139,5(F)$ & \\
\hline & & & & & & $231,2(F)$ & & $136,4(F)$ & \\
\hline & & & & & & $232,9(F)$ & & $140,0(F)$ & \\
\hline & & & & & & $241,0(F)$ & & $163,5(\mathrm{M})$ & \\
\hline & & & & & & $250,2(F)$ & & $166,5(\mathrm{M})$ & \\
\hline & & & & & & & & $238,6(F)$ & \\
\hline & & & & & & & & $198,5(F)$ & \\
\hline & & & & & & & & $163,0(F)$ & \\
\hline
\end{tabular}


Lampiran 3. Frekuensi panjang dan nisbah kelamin cucut lanjaman

Appendix 3. Length frequency and sex ratio of silky shark

\begin{tabular}{|c|c|c|c|c|}
\hline \multirow{2}{*}{$\begin{array}{l}\text { Kelas panjang/ } \\
\text { Length class } \\
\text { (cm) }\end{array}$} & \multirow{2}{*}{$\begin{array}{l}\text { Nilai tengah/ } \\
\text { Mid value } \\
(\mathrm{cm}) \\
\end{array}$} & \multicolumn{2}{|c|}{ Frekuensi/Frequncy (N) } & \multirow[b]{2}{*}{ Catatan/Note } \\
\hline & & $\begin{array}{l}\text { Betina/ } \\
\text { Female }\end{array}$ & $\begin{array}{c}\text { Jantan/ } \\
\text { Male }\end{array}$ & \\
\hline $51-60$ & 55 & 1 & - & \multirow{20}{*}{$\begin{array}{l}\text { Nisbah kelamin: } \\
\text { betina:jantan/sex rasio of } \\
\text { female and male= } \\
212: 220(49: 51 \%)\end{array}$} \\
\hline $71-80$ & 75 & 6 & 5 & \\
\hline $80,1-90$ & 85 & 8 & 11 & \\
\hline $90,1-100$ & 95 & 15 & 16 & \\
\hline $100,1-110$ & 105 & 11 & 5 & \\
\hline $110,1-120$ & 115 & 3 & 5 & \\
\hline $120,1-130$ & 125 & 6 & 17 & \\
\hline $130,1-140$ & 135 & 11 & 13 & \\
\hline $140,1-150$ & 145 & 15 & 11 & \\
\hline $150,1-160$ & 155 & 9 & 12 & \\
\hline $160,1-170$ & 165 & 7 & 12 & \\
\hline $170,1-180$ & 175 & 12 & 12 & \\
\hline $180,1-190$ & 185 & 18 & 13 & \\
\hline $190,1-200$ & 195 & 24 & 22 & \\
\hline $200,1-210$ & 205 & 21 & 14 & \\
\hline $210,1-220$ & 215 & 19 & 11 & \\
\hline $220,1-230$ & 225 & 15 & 10 & \\
\hline $230,1-240$ & 235 & 10 & 8 & \\
\hline $240,1-250$ & 245 & 7 & 11 & \\
\hline $250,1-260$ & 255 & 1 & 3 & \\
\hline \multicolumn{2}{|c|}{ Jumlah } & 212 & 220 & \\
\hline
\end{tabular}

